\title{
Risk Reflexity and the Information Interpretation Conflict under the Conditions of the Coronacrisis
}

\author{
A. V. Aleinikov ${ }^{a, *}$, G. G. Gazimagomedov ${ }^{a, * *}$, D. A. Maltseva ${ }^{b, * * *}$, \\ V. P. Miletskiy ${ }^{c, * * * *}$, and O. D. Safonova ${ }^{d, * * * * *}$ \\ ${ }^{a}$ Department of Conflictology, St. Petersburg University, St. Petersburg, Russia \\ ${ }^{b}$ Department of Theory and Philosophy of Politics, St. Petersburg University, St. Petersburg, Russia \\ ${ }^{c}$ Department of Sociology and Political and Social Processes, St. Petersburg University, St. Petersburg, Russia \\ ${ }^{d}$ Department of Political Institutions and Applied Political Science, St. Petersburg University, St. Petersburg, Russia \\ *e-mail: a.alejnikov@spbu.ru \\ **e-mail:g.gazimagomedov@spbu.ru \\ ***e-mail:d.maltseva@spbu.ru \\ ****e-mail:v.miletskiy@spbu.ru \\ *****e-mail: odsafonova@gmail.com \\ Received September 9, 2021
}

\begin{abstract}
The new design of the relationship between risk reflection and information management, the formation of trust in information in the context of the COVID-19 pandemic, and information parameters of the coronavirus crisis were investigated here. An analysis of the characteristics of the information interpretation conflict of risks and dangers has been carried out and a typology of risk reflections in assessing information about coronavirus has been proposed. The conflict potential of information flows that impose forms of risk perception and risk behavior, the mechanisms of formation of information inequality in the reflection of risks and the exclusion of social information in the policy of distribution and compensation of risk are revealed. Theoretical foundations for measuring behavior depending on the interpretation of information about risks are proposed, possible information tactics for risk management during conflicting interpretations are structured, and the characteristics of institutional failures in the field of information risk management are revealed.
\end{abstract}

Keywords: information, information risk management, coronavirus. infodemic, risk-reflection, risks, conflict of interpretations, pandemic

DOI: $10.3103 / \mathrm{S} 0147688221040067$

\section{INTRODUCTION}

The COVID-19 pandemic has reshaped the institutional parameters of information and communication structures. The denominator of the socio-political reflection of crises and the risks of a pandemic in theoretical and political-instrumental discourse was the title of the article by the World Bank Chief Economist Carmen Reinhart "This time truly is different" [1].

According to V.A. Mau [2], predictability and uncertainty of an enemy's actions, that is, a virus or the potential for a common existential threat provide a basis for drawing an analogy with war, which stimulates the search for information strategies for risk management and decision making in conditions of uncertainty, and a new design of communication.

According to W. Beck, the emergence of new communication mechanisms, methods, and forms of information exchange in the context of a structural crisis is a conflict between scientific and social knowl- edge, which consists in an antagonistic struggle for the definition of "what is risky and what is not." The inability to appropriate the constructive elements of risk reflections in the strategy of information management of threats, when managerial decisions are made in situations of uncertainty, destroys the state of security. According to the sociologist Viktor Vakhstein "Information about threats changes the everyday life of people ... It is important in what metaphor, logic, or framework information about the epidemic is presented ... A virus is not a coronavirus, but a language that is used ... The choice of the presentation format has much more serious consequences in what it seems to people who are trying to influence public opinion" [3].

Thus, the interconnection of risk reflection by citizens and information management and the formation of trust in information in the context of the COVID-19 pandemic is the leitmotif of theoretical and expert discussions. 
Nobel laureate Elinor Ostrom noted that the main internal source of uncertainty is the lack of knowledge [4].

In the modern socio-humanitarian landscape, we are witnessing an intensification of discussion of the phenomenon of conflict of interpretations of risks and dangers as the basis of many social conflicts. In the era of the pandemic, the information configurations of risk reflections have become the objects of close attention of modern social sciences.

The search for information parameters of pandemic risks is centered around the controversy about the problems of responsibility and accountability for risks, the definition of the characteristics of socially approved behavior in a pandemic, and adequate crisis communication strategies. This new situation is most succinctly reflected in political and sociological theoretical programs that address ways to conceptualize risk communication in the context of the fight against the epidemic. In this perspective it can be noted that in the scientific literature descriptions of communicative reactions to a unique situation of a combination of exogenous shocks and crisis political, managerial, and economic transformations are very contradictory. The dialectic of legitimization/delegimization of the control of the spread of COVID-19, the construction of scientific and expert information about the tools of a proactive response, taking the antagonistic definitions of the dangers of COVID-19 in both scientific and social discourse into account, is highlighted. An equally difficult issue is the long-term psychological and financial consequences, structural inequality, deepening social division, discrimination under the influence of COVID-19 of socio-economic strata, ethnic minorities, women, and the elderly [5].

The most important issue for making sense of the COVID-19 pandemic experience is the weak information and political response to social anxiety in the process of production, distribution, and management of risks. The factors of social change are associated with a crisis of trust in information.

In fact, the conclusions that were figuratively and emotionally formulated by A. Rubtsov became conventional in the sociology of the pandemic: "In the 'strange' and 'inadequate' (in other words, undesirable) reactions of the population, regulators see a deficit of reasonable responsibility of the instructed masses and not their own failures of communication. .... All this draws administrative structures and entire governments into a funnel of technical and then political unpredictability. The result is involuntary mutual provocations, as if one was specially inviting entire categories of the population to behave "inappropriately" [6].

Thus, we are dealing with a political and problematic situation; for its scientific understanding it is necessary to resolve a number of theoretical and methodological issues.

\section{THE INFORMATION CONFLICT \\ OF THE INTERPRETATION}

\section{AND RISK-REFLECTION OF PANDEMIC}

Nobel laureate Douglas North, emphasizing that "the world in which we live is nonergodic: it is a world of constantly emerging new changes.... new, fundamentally different types of uncertainty," identified five levels of uncertainty depending on the response of society.

1. The increase in information within the existing body of knowledge leads to an increase in predictability and the transformation of uncertainty into risk.

2. Increasing the volume of knowledge within the existing institutional framework.

3. Changing the institutional framework within the existing belief structure.

4. Changing the structure of beliefs.

5. Residual uncertainty, which serves as the basis for "irrational" beliefs; "in the case of a truly new phenomenon, we are faced with uncertainty, the consequences of which are simply unknown to us. In this case, the probability of successful reduction of uncertainty depends only on luck and the players will act on the basis of irrational beliefs" [7, pp. 30-40]. It is important that risk in this research tradition is understood as the danger of loss, when the degree of uncertainty or the likelihood of damage occurring can be measured. In this situation, communication under conditions of risk can determine the emergence of forms of alienation of the information product, "communicative exploitation."

"Communicative capitalism," according to the concept of Jody Dean [8], is characterized by:

- competition in the amount of information that forms inequality and the hierarchy of communicative capital;

- reflexivity, that is, the ability to generate many different and equally legitimate opinions, "endless doubt" [9];

- "the fantasy of information abundance," as characterized by the impossibility of highlighting the important and necessary in a huge information flow;

- "the fantasy of inclusion," where information technology turns into a fetish that replaces real political activity with simple communicative actions (polemics and commentary), the use of politicized information technology platforms;

- "the fantasy of unity and integrity," which is understood as the transformation of information platforms into "global zero institutions," where one of them politically appears as single and omniscient, excluding everything external $[10,11]$.

In this regard, the question seems reasonable: how does a modern social subject act in conditions of "uncoupling of risky communications," a combination of "communication abundance" and "communi- 
cation poverty," selectivity and politicization of the information flow, social inequality of access and the ways of using digital technologies? [12].

The remarks of the researchers, which fix a person's tendency to emotional personal faith and not to rational argumentation in questions of the danger of the coronavirus and the ways of preventing and treating it, seem to be well-grounded. Facts are replaced by meanings, while the person at risk in this information environment either constructs his own meaning, or focuses on the meaning that dominates in the information field [13].

We have already noted [14] that the intensification of the search for new approaches to the interpretation of the influence of the information conflict of interpretations on risk reflection is largely due to the cultivation of pathological affectations that determine the direction of the communication process of the constant exchange of risk perceptions.

When conceptualizing the phenomenon of riskreflection, we rely on the sociological model of different types of reflexivity by Margaret Archer, which define different positions in relation to risks and threats. The theoretical premise seems to be of fundamental importance, according to which risk-reflection is the questioning of a person in a threat situation "What's next?," while risk-reflexivity is "What should I do next with this?" At the same time, the boundaries between them are indistinct and reflection easily turns into reflexivity.

In this regard, it seems promising in the study of risk reflections to use the distinction of four types $[15,16]$ :

(1) communicative reflexivity-a type of reflexivity, in which a social subject needs to get approval of his actions from others before acting in a risky situation;

(2) autonomous reflexivity - the subject makes independent decisions about actions in conditions of uncertainty;

(3) metareflexivity-pronounced "internal conversation," a critical dialogue, in which the effectiveness of one's own action in a risky situation, as well as positive experience and selectivity in choosing forms of risky behavior, is critically assessed;

(4) broken or impaired reflexivity-inability to use power over oneself, lack of meaningfulness in actions in conditions of risk, disorientation, and situational expressiveness.

The problem is seen in the fact that the prevalence of "categorical and personal-superstitious thinking" (binary perception of danger and a tendency to personal superstition) in assessments of information about coronavirus increases the susceptibility of people to manipulative techniques and technologies regarding the coronavirus [17].

The destructive potential of destructive information, according to some scientists, is not inferior to the actual viral threat and even surpasses it; it is reflected in social fatigue from the epidemic ("bad infinity"), is an additional source of tension, leads to the loss of people's sense of belonging to society, loss of control by society due to the erosion of social norms, "the transformation of the norm into absurdity" (W. Beck), and ignoring the rules of behavior. This state is defined as social anomie, "abnormality," in which "some structures of society exert a certain pressure on individual members of society, pushing them more towards the path of insubordination than towards the path of behavior consistent with generally accepted rules" [18].

The coronavirus pandemic has exacerbated the problem of the hierarchy of risks; in the modern world, the logic of "distribution of wealth in society" has been replaced by the "logic of risk distribution" [19, p. 21]. The situation is complicated by the fact that in modern society there is always a conflict between the interpretations of risk, and "the cognitive equipment of thinking with the images of Other-one's own and the Other-someone else's allows us to identify the situation as a conflict, problematization, and decision making” [20, p. 79].

\section{INFORMATION AND DISINFORMATION IN THE SUBSPACE OF RISK}

In risk-reflection, information and misinformation are elements of the reflection of the dominant discourse of power, which determines what is risky and what is not, and who belongs to the groups that are in the zone of special risk. According to L. Coser, "in extremely polarized social systems where internal conflicts of different types are superimposed on each other, a single reading of the situation and a common perception of events by all members of the system are hardly possible at all" [21]. Thus, in information flows that impose forms of risk perception and risk behavior, seemingly reasoned descriptions of risks conflict with management practices that enhance the functionality of prevention and distribution of threats, which are often interpreted as something irrational and fictitious.

In the system of stratification of risks and threats of the bipolar society of information capitalism, the social polarization of producers and consumers of information about threats, as well as the issue of the distributive fairness of risks and who should bear the burden of their costs, is especially acute. An analysis of M. Castells's theory shows that such institutional practices are "fundamental social faults in the information age" [22].

In fact, we are talking about the processes and mechanisms of formation of information inequality of reflection of risks, the growth of social information exclusion in the policy of distribution and compensation of risk, "exploitation of the second order" [23], which entails preferences in a situation of threat to any 
social group to the detriment of others, since the risks are hierarchical, and they are more exposed to the strata of society that are least capable of minimizing their consequences [24].

In this regard, P. Shtompkoy proposed the concept of trauma as a certain pathology of society, when the context of human life and social action loses homogeneity, consistency, and stability. Traumatic events cause a violation of the usual way of thinking and acting, and change people's worlds, as well as their models of behavior and thinking, often tragically [25].

The observation of Yu. Kimelev and N. Polyakova that today the possibility and ability of the individual as a subject of social action to realize, comprehend, and actualize the potential of the comprehensibility of social historical reality and its potential transformability is questioned [26].

At the same time, in the "risk subspace," which we, using the methodology of P. Bourdieu, consider an asymmetric structure of production, reproduction, ranking, and distribution of threats and risks that function simultaneously as a tool and goal of struggle in the information field [27], the blocking and substitution of feedback information increases, the value of information injections and provocations increases, as well as threats and manipulation of the effects of dangers (or their imitation). One can agree with the position of Dmitry Evstafiev that "the networked information society has demonstrated the absence of built-in mechanisms to protect society against information manipulations. The public involved in information processes has basically come to terms with the manipulative nature of today's information society, which is proved not only by the lack of efforts to neutralize the processes of the fake information space, but by the signs of political legalization of such fakes" [28].

In the context of the "reproducible algorithm of successful extreme behavior without rules" [29] that is characteristic of the COVID-19 pandemic, post-traumatic stress syndrome is enhanced by reflexivity, that is, the ability of social actors (individuals and groups of individuals) to interpret their own actions and the actions of other people or social events, which influences the decisions they make.

\section{REFLEXIVE RISK INFORMATION MANAGEMENT}

The perceived value of a risk depends on the "subjective assessment of the probability of the event occurring" asserted by $\mathrm{O}$. Rennes [30].

If information is aimed at quantitative indicators of risk (for example, vaccination or severe cases of the course of the disease), then strategies for avoiding danger, risk avoidance, are obvious, while the more actively the information flow allows a reasonable risk or considers it the norm, the higher the desire is to meet the danger.
We believe that explanations of how the interpretation of information about hazards and the recognition of certain risks as socially acceptable are related, and how this relationship affects the effectiveness of political decisions on threat management, can be described based on the concept of life styles of G.P. Müller [31]. It involves the comprehension of structured patterns of behavior in the face of risk, depending on information resources at the disposal of risk producers and consumers, and their value attitudes. Following Müller, there are four main dimensions of behavior, depending on the interpretation of risk information:

- expressive (the tendency to seek strong sensations, when the possibility of loss is justified by the subjective value of pleasure);

- interactive (risk taking due to circumstances with an independent choice of forms of action);

- value (a conscious and value-based attitude to risk, assessment of the possibility of loss of one and the value of the other);

- cognitive (self-identification in a risk society perceived on the basis of information when making a decision in a situation of danger).

Proceeding from this, explanatory models of the perception of risk acceptability and its admissibility are built in the information flow either on the assessments of the political and emotional perception of the scale of "honesty" of their distribution, or on the analysis of decisions based on certain normative principles and methods of substantiating assessments of threats and dangers.

At the same time, it is important that "reflexive control" [32] corrects the hierarchy of the significance of risks in a multilevel system of feedback loops, "determining the dependence of conditions, principles, norms, etc. (including control actions) on previous and current performance results and uncertainties" [33].

As examples, regarding information tactics of risk management during a pandemic, we observe [34]

- information seduction of the person at risk by praising their merits. At the same time, it is important if the person at risk realizes that the desire to make an impression (for example, the actions of the authorities when organizing vaccination) is associated with concern for their own benefit; then, any manifestation of seductive behavior will be regarded as manipulation;

- seduction of the person at risk by creating an impression of mutual similarity;

- seduction of the person at risk through the provision of services;

- ruffling of feathers (to confuse or weaken one's persistence) is aimed at lulling the suspicions of the person at risk by actions allegedly aimed at their benefit, or by creating in them a sense of irresponsibility and incompetence. This tactic is successful when con- 
fused people are unaware that they were deliberately brought to confusion;

- hidden reproaches, here, under the guise of harmless remarks about real facts, one can create remorse;

- convincing argumentation, persuading a person to reduce their claims with the help of logical arguments;

- information containing threats to harm;

- tactics of inviolable obligations, when threats are built according to the principle if ... then (risky producers declare that they will behave in a certain way, and persons at risk need to adapt to this).

\section{CONCLUSIONS}

The pandemic has introduced many changes in the problem of reflexive information management in a risky situation. Thus, the Director General of the World Health Organization Tedros Ghebreyesus has declared a fight not only against the epidemic of the disease, but also against the information epidemic: "Fabricated news spreads faster and more easily than a virus and is no less dangerous" [36].

In this regard, a number of researchers have introduced the extremely important concept of infodemia (too much information), which is an overabundance of information of varying degrees of accuracy about the virus, coupled with political discourse, including fake, partially truthful, false, and deliberately misleading information, which provokes risky behavior and distrust of the authorities and the health care system [36]. At the same time, some note in parallel the phenomenon of datademia (an excess of data on the epidemic, statistics of diseases, etc.) [37].

Information in the field of risk management is aimed, among other things, at minimizing the results of a conflict of interpretations, whose results may well reject rational decisions and lead to unrealistic optimism or unrealistic pessimism in the perception of threats and dangers, risk phobia or riskophilia, and social ideas about strategies of behavior in conditions of vulnerability. In this situation, the entire society is at risk, aimed at maximizing popularity in information management, since, in responding to the perception of risks by the majority, it is outside the zone of effective solutions for managing threats [38]. The paradox of management, which is bad from the point of view of the effectiveness of information risk management, is that it costs society dearly and deforms stabilizing mechanisms, while, nevertheless, it is attractive and politically convenient [39].

A.Ya. Rubinstein proposed an original typology of managerial failures [40]. Using this approach, in the field of information risk management, one can distinguish institutional, distributive (unacceptable distribution of risks), and behavioral (irrational behavior of citizens in situations of uncertainty, threats and dan- gers) failures. The characteristics of information institution failures include

- information violations of a reasonable degree of risk differentiation, where the best of the worst options for responding to threats is chosen, rather than the optimal one;

- focus of information on polarization and radicalization of positions on the issues of determining the acceptability of risk;

- information discoordination in the choice of risk alternatives and the order of steps for its prevention;

- stimulation of the appearance of threat goods on the information market;

- asymmetric and distorted information or lack of information about real, predictable, perceived or artificial threats (illusions of risk and concern for society), systematic bluffing, and increasing rates;

- in a situation of threats in information coping strategies, the domination of compensation occurs for social fears of a huge increase in one's own importance, that is, herostratism and the desire to harm strangers;

- uncoordinated information on social programs to minimize risks and probable retribution for their implementation;

- imposition of norms and rules of behavior under uncertainty in the absence of good options that bring the greatest utility (a zero or constant sum game, excluding compromises);

- incorrect regulatory and legal settings in the fields of forecasting and preventing risks;

- imitation of regulation of the level of risk, its controllability and double standards in determining the acceptable level of risk for various social groups;

- substitution of goal setting when making decisions in information risk management (masking goals when making unpopular political management decisions in a situation of danger or forbidding the discussion of results/indicators of achieving goals of eliminating and or minimizing risk).

To sum up, it should be emphasized that a conflict of interpretations of information about the dangers of a virus arises in the event of a collision of two main information models for combating a pandemic: solidarity and absintheist [41]. Solidarity is the purposeful formation in the society of support for measures to manage the coronavirus crisis based on trust in information about the scale and consequences of the epidemic; absinthe is vague or fatalistic reflexivity of a threat, contradictory information flows on the part of the authorities about the risks and dangers of the epidemic, and manipulation of statistical data and restrictive measures.

Thus, there is reason to believe that information management of risks should be studied from the standpoint of analyzing the characteristics of their 
perception, that is, the risk reflexivity of information flows about the coronacrisis.

\section{FUNDING}

The work is supported by the Russian Science Foundation, project no. 19-18-00115.

\section{CONFLICT OF INTEREST}

The authors declare that they have no conflicts of interest.

\section{REFERENCES}

1. Reinhart, C., This time truly is different, Project Syndicate, 2020. https://www.project-syndicate.org/ commentary/covid19-crisis-has-no-economic-precedentby-carmen-reinhart-2020-03. Cited September 6, 2021.

2. Mau, V.A., Coronavirus pandemic and trends of economic policy, Vopr. Ekon., 2021, no. 3, pp. 5-30. https://doi.org/10.32609/0042-8736-2021-3-5-30

3. Aleksandrova, E., Will the Wuhan treat change our life and ourselves? A sociologist about the influence of epidemy on the society, Telekanal Nauka, 2020. https://naukatv.ru/articles/710. Cited September 6, 2021.

4. Ostrom, E., Upravlyaya obshchim. Evolyutsiya institutov kollektivnoi deyatel'nosti (Managing the Collective: Evolution of Institutes of Collective Activity), Moscow: IRISEN, Mysl', 2010.

5. Rollston, R. and Galea, S., The coronavirus does discriminate: How social conditions are shaping the COVID-19 pandemic, Harvard Med. School Primary Care Rev., 2020. http://info.primarycare.hms.harvard. edu/review/social-conditions-shape-covid. Cited September 6, 2021.

6. Rubtsov, A., Viruses and civilizations. The new impact of biocataclysms on the evolution of sociocultural models and civilization projects, Vopr. Filos., 2020, no. 8, pp. 20-31.

https://doi.org/10.21146/0042-8744-2020-8-20-31

7. North, D.C., Understanding the Process of Economic Change, The Princeton Economic History of the Western World, vol. 32, Princeton: Princeton Univ. Press, 2010. https://doi.org/10.1515/9781400829484

8. Dean, J., Communicative capitalism: From dissent to division, Kommun. Media. Dizain, 2017, vol. 2, no. 3, pp. 152-165.

9. Gavra, D. and Dekalov, V., The concept of communicative capitalism: Methodological premises and paradigmatic positioning, Zh. Sotsiol. Sots. Antropol., 2018, vol. 21 , no. 1 , pp. $27-43$. https://doi.org/10.31119/jssa.2018.21.1.2

10. Dean, J., Communicative capitalism: circulation and the foreclosure of politics, Cultural Polit., 2005, vol. 1, no. 1, pp. 51-74. https://doi.org/10.2752/174321905778054845

11. Safronov, E.E., Jodi Dean's concept of communicative capitalism, Znanie. Ponimanie. Umenie, 2020, no. 1, pp. $236-247$.

https://doi.org/10.17805/zpu.2020.1.20
12. Keane, J., Democracy and Media Decadence, New York: Cambridge Univ. Press, 2013.

13. Chumikov, A.N., The modern information field: Senses, problems, communications solutions, Ross. Shkola Svyazei Obshchestvennost'yu, 2015, no. 6, pp. 32-43.

14. Aleinikov, A.V., Kurochkin, A.V., and Maltseva, D.A., Information management under the conditions of global pandemic, Sci. Tech. Inf. Process., 2021, vol. 48, no. 1 , pp. 38-44. https://doi.org/10.3103/S0147688221010068

15. Archer, M.S., Structure, Agency and the Internal Conversation, Cambridge: Cambridge Univ. Press, 2003.

16. Kuchinov, A.M., Margaret Archer's theory of social morphogenesis and reflectivity, Metod: Mosk. Ezhegod. Tr. Obshchestvovedcheskikh Distsiplin, 2017, no. 7, pp. 365-392.

17. Boiko, O.M., Medvedeva, T.I., Enikolopov, S.N., Vorontsova, O.Yu., and Kazmina, O.Yu., The psychological state of people during the COVID-19 pandemic and the target of psychological work, Psikhol. Issled., 2020, vol. 13, no. 70, p. 1.

18. Merton, R.K., Social structure and anomy, Sotsiol. Vlasti, 2010, no. 4, pp. 212-223.

19. Beck, U., Risk Society-Towards a New Modernity, London: Sage, 1992.

20. Makarov, A.I., Enemy image in territory conflicts: Methodological aspects, Sotsial'nyi konflikt v razlichnykh normativno-semioticheskikh sistemakh (Social Conflict in Different Normative-Semiotic Systems), Letyaev, V.A., Ed., Kazan: Inst. Istorii Kazan. Univ., 2012, pp. 77-92.

21. Coser, L.A., The Functions of Social Conflict, New York: Routledge, 1956.

22. Castells, D.M., The Rise of the Network Society, Oxford: Blackwell Publishers, 1996.

23. Gorz, A., L'Immatériel: Connaissance, valeur et capital, Paris: Galilée, 2003.

24. Tierney, K.J., Toward a critical sociology of risk, Sociol. Forum, 1999, vol. 14, no. 2, pp. 215-242.

https://doi.org/10.1023/A:1021414628203

25. Sztompka, P., Cultural trauma: The other face of social change, Europ. J. Soc. Theory, 2000, vol. 3, no. 4, pp. 449-466.

https://doi.org/10.1177/136843100003004004

26. Kimilev, Yu. and Polyakova, N., Modern i protsess individualizatsii: istoricheskie sud'by individa moderna (Modern and the Individualization Process: Historical Destinies of a Modern Individuum), Moscow: Praksis, 2017.

27. Aleinikov, A.V., Artemov, G.P., and Pinkevich, A.G., Risk reflections as a factor for choosing forms of political participation (results of the All-Russian survey), Vestn. Ross. Univ. Druzhby Narodov, 2020, no. 4, pp. $847-863$.

https://doi.org/10.22363/2313-2272-2020-20-4-847-863

28. Evstafiev, D.G., Crisis of a modern information society as reflection of crisis of the global world, Svobodnaya Mysl', 2021, no. 1, pp. 163-176.

29. Pavlovskii, G.O., Ironicheskaya imperiya. Risk, shans $i$ dogmy Sistemy RF (Ironic Empire: Risk, Chance, and Dogmas of RF System), Moscow: Evropa, 2019. 
30. Renn, O., Three decades of risk research: successes and new horizons, Vopr. Anal. Riska, 1999, no. 1, pp. 80-99.

31. Müller, H.-P, Lebensführung: Eine systematische Skizze im Anschluss an Max Webers Forschungsprogramm, Alte Begriffe - Neue Probleme: Max Webers Soziologie im Lichte aktueller Problemstellungen, Schwinn, T. and Albert, G., Eds., Tübingen: Mohr Siebeck, 2016, pp. 249267.

32. Lefevr, V.A., Konfliktuyushchie struktury (Conflicting Structures), Moscow: Sovetskoe Radio, 1973.

33. Belov, M.V. and Novikov, D.A., Models of experience, Probl. Upr., 2021, no. 1, pp. 43-60. https://doi.org/10.25728/pu.2021.1.5

34. Rubin, J.Z., Pruitt, D.G., and Kim, S.-H., Social Conflict: Escalation, Stalemate, and Settlement, McGrawHill, 1994, 2nd ed.

35. Ghebreyesus, T.A., Lecture of the President of the World Health Organization at the Munich Security Conference, 2020. https://www.who.int/director-general/ speeches/detail/munich-security-conference. Cited September 6, 2020.

36. Mheidly, N. and Fares, J., Leveraging media and health communication strategies to overcome the
COVID-19 infodemic, J. Public Health Policy, 2020, vol. 41 , no. 4 , pp. $410-420$.

https://doi.org/10.1057/s41271-020-00247-w

37. Pollock, J.C. and Vakoch, D.A., COVID-19 in International Media: Global Pandemic Perspectives, New York: Routledge, 2021.

38. Rubinshtein, A.Ya. and Gorodetskii, A.E., State paternalism and paternalist failure in the theory of patronized good, Zh. Institutional. Issled., 2018, vol. 10, no. 4, pp. $38-57$.

https://doi.org/10.17835/2076-6297.2018.10.4.038-057

39. Baland, J.-M., Moene, K.O., and Robinson, J.A., Governance and development, Handbook of Development Economics, Elsevier, 2010, vol. 5, pp. 4597-4656. https://doi.org/10.1016/B978-0-444-52944-2.00007-0

40. Rubinshtein, A.Ya., Elements of the general theory of the mixed economy defects, Vopr. Gos. Munitsipal'nogo Upr., 2017, no. 1, pp. 71-102.

41. God kovida: Predvaritel'nye itogi i vyzovy desyatiletiya (COVID Year: Preliminary Results and Challenges of the Decade), Rogov, K., Ed., Moscow: Liberal'naya Missiya, 2021. 